\title{
Pathogenicity of Pratylenchus brachyurus to rubber rootstocks
}

\author{
Marcos Silveira Bernardes ${ }^{1}$ e Adriana Novais Martins ${ }^{2}$
}

\begin{abstract}
${ }^{1}$ Crop Production Department, Escola Superior de Agricultura “Luiz de Queiroz”, ESALQ/USP, Caixa Postal 9, Piracicaba-SP, 13418-900, Brazil, marcosbernardes@usp.br. ${ }^{2}$ APTA Centro Oeste, R. Andrade Neves, 81, Cascata, Marília-SP, 17515-400, Brazil, adrianamartins@apta.sp.gov.br Autor para correspondência: Marcos Silveira Bernardes (marcosbernardes@usp.br)

Data de chegada: 29/11/2013. Aceito para publicação em: 16/01/2015.
\end{abstract}

$10.1590 / 0100-5405 / 1956$

\section{ABSTRACT}

Bernardes, M.S.; Martins, A.N.. Pathogenicity of Pratylenchus brachyurus to rubber rootstocks Summa Phytopathologica, v.41, n.1, p.31-34, 2015.

The pathogenicity of Pratylenchus brachyurus to rubber (Hevea brasiliensis) rootstocks was studied in two experiments: 1) opencross seedlings of 'Tjir 1' $\mathrm{x}$ 'Tjir 16' were inoculated with zero, 7,700 or 23,100 nematodes per plant; 2) illegitimate seedlings of 'GT 1', 'RRIM $527^{\prime}$ ' and 'RRIM 600 ' were inoculated with zero or 12,800 nematodes per plant. After 195 ( $1^{\text {st }}$ experiment $)$ or 105 days after inoculation $\left(2^{\text {nd }}\right.$ experiment), $P$. brachyurus did not affect the relative growth percentage in terms of plant height in both experiments but significantly diminished the stem diameter percentage and increased the stomatal resistance of 'GT 1', 'RRIM 527' and 'RRIM 600'.

Additional keywords: Hevea, nematodes, nursery

\section{RESUMO}

Bernardes, M.S.; Martins, A.N.. Patogenicidade de Pratylenchus brachyurus a porta-enxertos de seringueira. Summa Phytopathologica, v.41, n.1, p.31-34, 2015.

A patogenicidade de Pratylenchus brachyurus a porta-enxertos de seringueira (Hevea brasiliensis) foi estudada em dois experimentos: 1) plântulas de cruzamento aberto de 'Tjir 1' $x$ 'Tjir 16' foram inoculadas com zero, $7.700 \mathrm{ou}$ 23.100 nematóides por planta; 2) plântulas ilegítimas de 'GT 1', 'RRIM 527'e 'RRIM 600' foram inoculadas com zero ou 12.800 nematóides por planta. Após
195 ( $1^{\circ}$ experimento) ou 105 dias ( $2^{\circ}$ experimento), P. brachyurus não havia afetado a porcentagem de crescimento relativo, em termo de altura das plantas em ambos os experimentos, porém diminuiu significativamente a porcentagem de crescimento em diâmetro do caule e a resistência estomática de 'GT 1', 'RRIM 527'e 'RRIM 600'.

Palavras-chave adicionais: Hevea, nematodes, nursery

The nematode Pratylenchus brachyurus (Godfrey) has been found infecting roots of rubber plants (Hevea brasiliensis) presenting reduced growth in Brazil $(10,11)$ and in Malaysia (19). Rao (14) also reported the incidence of root lesion nematodes Pratylenchus coffeae on rubber in Indonesia. Although P. brachyurus was the main responsible for the injuries observed on those occurrences, and even though its dissemination and damages stand together with Meloydogyne spp. as the most important for this crop (12), until recently it was not yet considered a pathogen of rubber, and infected plants were still used as planting material. Consequently, in a survey carried out in rubber nurseries in São Paulo State in 2013, more than $60 \%$ of the roots revealed to be infected by $P$. brachyurus (13). To avoid dissemination by its most important means, national (1) and state (17) regulations now restricted the use to only nematode-free planting material. Opencross seeds of 'Tjir 1' $x$ 'Tjir 16' and illegitimate seeds of 'GT 1' and 'RRIM 600' are the most traditional, recommended and available seeds, respectively, to produce rootstocks in rubber nurseries $(5,12)$. The aim of the present study was to identify the damage caused by $P$. brachyurus in young rubber rootstock plants. For that purpose, two experiments were conducted in Piracicaba, Brazil.

\section{MATERIAL AND METHODS}

In both experiments, rubber seeds were germinated in sterilized sand, and seedlings transplanted to polybags containing $2 \mathrm{~L}$ of sterilized soil. Rubber rootstocks were inoculated when they presented the first vegetative flush with completely expanded and mature leaves in stage "D", according to Hallé \& Martin (6). Nematodes were isolated from corn roots, multiplied in alfalfa (Medicago sativa) callus, according to the method proposed by Riedel et al. (15), and extracted with modified Baermann funnels (18). Inoculation was done with a suspension of nematode which was pipetted in a circular groove on the soil around the plants. The groove was covered with soil afterwards. Tomato plants (Lycopersicon esculentum Mill.), as good hosts of P. brachyurus (8), were also inoculated with 7,000 nematodes per plant in the first and 12,800 in the second experiment to confirm the infectiveness of the nematode suspension. At the end of the experiments, nematodes were extracted from the roots by the method described by Coolen \& D'Herde (4) and counted.

Plant growth was evaluated through the measurement of plant height and stem diameter at $5 \mathrm{~cm}$ above ground on the inoculation 
day and in two subsequent times during the experimental period. The growth percentage over the periods, in terms of height and diameter, was calculated based on the following formula: (actual measurementinitial measurement)/initial measurement x 100 .

In the first experiment, rootstocks were obtained from opencross seeds of 'Tjir 1' $x$ 'Tjir 16' collected in ground from a 60-year-old rubber field at Colina-SP. The plants were kept in plastic-cover greenhouse, within a temperature range from $15^{\circ} \mathrm{C}$ to $25^{\circ} \mathrm{C}$, and daily irrigated during the experimental period, from May 22 to December 23. The experiment was done in completely randomized design, with the three following treatments: zero; 7,700 (lowest dose) or 23,100 (highest dose) nematodes inoculated per plant. There were eight replicates, and one plant per replicate. Measurements were done at 104 and 195 days after inoculation (AI), and nematodes were extracted from the roots and counted at 214 days AI.

In the second experiment, rootstocks were obtained from illegitimate seeds of 'GT 1', 'RRIM 527' and 'RRIM 600' collected from mature fruits, kept in the mother-tree, from the Rubber Seed Garden of ESALQ-USP, Piracicaba-SP, by using small nets to avoid dispersion to the ground and to guarantee their genetic precedence and sanity. The plants were kept in glasshouse, within a temperature range from $18^{\circ} \mathrm{C}$ to $32^{\circ} \mathrm{C}$, and daily irrigated during the experimental period, from August 21 to January 07 of following year. The experiment was done in factorial design $(2 \times 3)$, with 2 inoculation levels (inoculated with zero or 12,800 nematodes per plant) by 3 genetic ancestral lines ('GT 1', 'RRIM 527', 'RRIM 600'), and eight replicates, with one plant per replicate. Measurements were done at 63 and 105 days AI, and nematodes were extracted from the roots and counted at 136 days AI. Stomatal resistance $\left(\mathrm{r}_{\mathrm{s}}\right.$ ) was estimated by using a dynamic diffusion porometer type AP4 (Delta $\mathrm{T}^{\circledR}$ ) on the dorsal surface of the central leaflet of the upper foliar flushing with completely expanded and mature leaves in stage "D", according to Hallé \& Martin (6). Measurements were carried out at around 10 o'clock, the period with smallest fluctuation estimates.

Results underwent analysis of variance and means were compared according to Tukey's test by using the procedures of SANEST computer program (20).

\section{RESULTS}

The results from the first experiment showed that, with the inoculated number of nematodes and during the experimental period, $P$. brachyurus did not significantly affect the growth percentage in terms of plant height and stem diameter (Table 1). The average number of nematodes extracted, at the end of the experiment, from the roots of rubber plants was substantially smaller (none for dose zero, 156 per plant for the lowest dose, and 426 for the highest dose), compared to that from the roots of tomato plants $(7,886$ per plant, extracted at 87 days AI). This suggests that $P$. brachyurus poorly reproduces in rootstocks from opencross of 'Tjir 1'x 'Tjir 16'.

In the second experiment, there were not significant differences in plant height, due to $P$. brachyurus infestation, among all the seedling families. Plant height was not sensitive to $P$. brachyurus infestation under the experimental conditions (Table 2). On the other hand, stem diameter was significantly reduced in infected plants of all three seedling families. For 'GT 1' and 'RRIM 600', this effect was observed at the end of the experimental period, at 105 days AI (Table 3). For 'RRIM 527', this effect was identified earlier, at 63 days AI, but slightly reduced at the end of the experiment, suggesting a growth recovery from the nematode infestation damage. The average number of nematodes extracted, at the end of the experiment, from the roots of rubber plants was substantially smaller (none for dose zero, 1,157 for 'GT 1', 1,679 for 'RRIM 527' and 839 for 'RRIM 600' per inoculated plant), compared to that from the roots of tomato plants (7,044 per plant, extracted at 63 days AI). This indicates a slower reproduction rate of $P$. brachyurus in these rubber rootstocks despite the low number of nematodes in the tomato root, compared to other findings $(7,9)$, which suggests a poor infectiveness of the nematode inoculating suspensions. Therefore, a broader range of nematode concentrations should be tested to confirm the present trends. Nevertheless, the present results clearly

Table 1. Growth percentage, means of eight replicates, in terms of plant height and stem diameter, for 'Tjir 1' x 'Tjir 16' rootstock, at 104 and 195 days after inoculation with different Pratylenchus brachyurus suspensions.

\begin{tabular}{cccccc}
\hline Treatment & \multicolumn{2}{c}{ plant } & height & & \multicolumn{2}{c}{ stem diameter } \\
\cline { 2 - 3 } \cline { 5 - 6 } & $104 \mathrm{~d}$ & $195 \mathrm{~d}$ & & $104 \mathrm{~d}$ & $195 \mathrm{~d}$ \\
\hline zero nematodes & $66 \% \mathrm{a}$ & $148 \% \mathrm{a}$ & & $18 \% \mathrm{a}$ & $55 \% \mathrm{a}$ \\
7,700 nematodes & $62 \% \mathrm{a}$ & $151 \% \mathrm{a}$ & & $20 \% \mathrm{a}$ & $58 \% \mathrm{a}$ \\
23,100 nematodes & $65 \% \mathrm{a}$ & $111 \% \mathrm{a}$ & & $24 \% \mathrm{a}$ & $57 \% \mathrm{a}$ \\
\hline C.V. & $32 \%$ & $34 \%$ & $50 \%$ & $48 \%$ \\
\hline
\end{tabular}

a Means in the same column, followed by the same letter, are not significantly different according to Tukey>s test $(\mathrm{P} \geq 0.05)$.

Table 2. Plant height growth percentage, means of eight replicates, for 'GT 1', 'RRIM 527' and 'RRIM 600' rootstock, at 63 and 105 days after inoculation with different Pratylenchus brachyurus suspensions.

\begin{tabular}{|c|c|c|c|c|}
\hline \multirow[t]{3}{*}{ Rootstock } & \multicolumn{2}{|c|}{63 days } & \multicolumn{2}{|c|}{105 days } \\
\hline & zero & 12,800 & zero & 12,800 \\
\hline & nematodes & nematodes & nematodes & nematodes \\
\hline GT 1 & $28 \% \mathrm{a}$ & $32 \% \mathrm{a}$ & $120 \%$ a & $95 \% \mathrm{a}$ \\
\hline RRIM 527 & $13 \% \mathrm{a}$ & $10 \%$ a & $47 \% \mathrm{a}$ & $44 \%$ a \\
\hline RRIM 600 & $36 \% \mathrm{a}$ & $26 \%$ a & $86 \%$ a & $67 \%$ a \\
\hline msd & \multicolumn{2}{|c|}{$24 \%$} & \multicolumn{2}{|c|}{$28 \%$} \\
\hline $\mathrm{CV}$ & \multicolumn{2}{|c|}{$40 \%$} & \multicolumn{2}{|c|}{$38 \%$} \\
\hline
\end{tabular}

a Means in the same measurement date and row, followed by the same letter, are not significantly different according to Tukey>s test (P $\geq 0.05)$. 
Table 3. Stem diameter growth percentage, means of eight replicates, for 'GT 1', 'RRIM 527' and 'RRIM 600' rootstock, at 63 and 105 days after inoculation with different Pratylenchus brachyurus suspensions.

\begin{tabular}{|c|c|c|c|c|}
\hline \multirow[t]{3}{*}{ Rootstock } & \multicolumn{2}{|c|}{63 days } & \multicolumn{2}{|c|}{105 days } \\
\hline & zero & 12,800 & zero & 12,800 \\
\hline & nematodes & nematodes & nematodes & nematodes \\
\hline GT 1 & $27 \%$ a & $15 \%$ a & $79 \%$ a & $54 \%$ b \\
\hline RRIM 527 & $33 \% \mathrm{a}$ & $19 \% \mathrm{~b}$ & $60 \%$ a & $42 \%$ a \\
\hline RRIM 600 & $19 \% \mathrm{a}$ & $14 \% \mathrm{a}$ & $65 \% \mathrm{a}$ & $41 \% \mathrm{~b}$ \\
\hline $\mathrm{msd}$ & \multicolumn{2}{|c|}{$13 \%$} & \multicolumn{2}{|c|}{$20 \%$} \\
\hline $\mathrm{CV}$ & \multicolumn{2}{|c|}{$37 \%$} & \multicolumn{2}{|c|}{$32 \%$} \\
\hline
\end{tabular}

a Means in the same measurement date and row, followed by the same letter, are not significantly different according to Tukey>s test (P $\geq 0.205)$.

Table 4. Stomatal resistance ( $\mathrm{r}_{\mathrm{s}}$ ), means of eight replicates, for 'GT 1', 'RRIM 527' and 'RRIM 600' rootstock, at 63 and 105 days after inoculation with different Pratylenchus brachyurus suspensions.

\begin{tabular}{|c|c|c|c|c|}
\hline \multirow[t]{4}{*}{ Rootstock } & \multicolumn{2}{|c|}{63 days } & \multicolumn{2}{|c|}{105 days } \\
\hline & zero & 12,800 & zero & 12,800 \\
\hline & nematodes & nematodes & nematodes & Nematodes \\
\hline & $\left(\mathrm{s} \mathrm{cm}^{-1}\right)$ & $\left(\mathrm{s} \mathrm{cm}^{-1}\right)$ & $\left(\mathrm{s} \mathrm{cm}^{-1}\right)$ & $\left(\mathrm{s} \mathrm{cm}^{-1}\right)$ \\
\hline GT 1 & $5.1 \mathrm{a}$ & $7.3 \mathrm{~b}$ & $6.1 \mathrm{a}$ & $8.4 \mathrm{~b}$ \\
\hline RRIM 527 & $9.4 \mathrm{a}$ & $13.3 \mathrm{~b}$ & $10.1 \mathrm{a}$ & $11.9 \mathrm{a}$ \\
\hline RRIM 600 & $6.2 \mathrm{a}$ & $8.1 \mathrm{~b}$ & $6.4 \mathrm{a}$ & $9.2 \mathrm{~b}$ \\
\hline msd & \multicolumn{2}{|c|}{1.9} & \multicolumn{2}{|c|}{2.3} \\
\hline $\mathrm{CV}$ & \multicolumn{2}{|c|}{$22 \%$} & \multicolumn{2}{|c|}{$31 \%$} \\
\hline
\end{tabular}

a Means in the same measurement date and row, followed by the same letter, are not significantly different according to Tukey>s test (P $\geq 0.205)$.

point out the negative effect of nematode occurrence in the roots of rubber plants on their growth.

Visual symptoms of nematode infection on roots were more evident in plants of 'GT 1' and 'RRIM 600' than in those of 'RRIM 527', although the average number of extracted nematodes was similar, suggesting a stronger sensitiveness of those genetic ancestral lines. Further and more detailed studies should be conducted to identify the sensitivity and tolerance of rubber rootstocks to nematodes, enlarging the number of genetic variability and including the most promising rootstocks, pointed by Cardinal et al. (3) as 'PB 235' and 'IAN 873'. The recommendation by Gonçalves et al. (5) for ' GT 1' rootstock, the most sensitive to $P$. brachyurus in the present study, should be reconsidered once this planting material may enhance the spread of the nematode. The pathogenicity to rubber of a broader range of nematodes needs to be evaluated, particularly those identified in the study of Paes et al. (13).

Stomatal resistance (Table 4) on control plants (zero nematodes) was similar to the data presented by Brunini \& Cardoso (2) and Rocha Neto et al. (16) for rubber seedlings without water stress and that on inoculated plants was comparable to the values of rubber seedlings subjected to 4 to 7 days of water stress. These findings suggest malfunctioning of the root systems of the infected plants. In future studies, other rubber plant variables, like root and stem fresh and dry weight and physiological parameters, should be measured to improve the understanding of nematode effects, similarly to the study of Inomoto et al. (8).

\section{CONCLUSIONS}

The results of both experiments showed that $P$. brachyurus infected all four rubber rootstock ancestral lines. P. brachyurus showed to be pathogenic for 'GT 1' and 'RRIM 600' illegitimate seedling families, in which it has significantly diminished the stem diameter growth, an important parameter related to budding success and future tree growth and yield.

\section{REFERENCES}

1. Brasil. Instrução Normativa $n^{\circ} 29$. Normas para produção sementes e de mudas de seringueira (Heva spp.). Diário Oficial da União, Brasília, DF, 06 de Agosto de 2009, n. 149, seção 1, p. 5-8.

2. Brunini, O.; Cardoso, M. Efeito do déficit hídrico no solo sobre o comportamento estomático e potencial da água em mudas de seringueira. Pesquisa Agropecuária Brasileira, Brasília, DF, v.33, n.7, p.1053-1060, 1998.

3. Cardinal, A.B.B.; Gonçalves, P. de S.; Martins, A.L.M. Stock-scion interactions on growth and rubber yield of Hevea brasiliensis. Scientia Agricola, Piracicaba, SP, v.64, n.3, p. 235-240, 2007.

4. Coolen, W.A.; D'Herde, C.J. A method for the quantitative extraction of nematodes from plant tissue. Ghent: State Nematology and Entomology Station, $1972.77 \mathrm{p}$

5. Gonçalves, E.C.P. (Coord.) A cultura da serigueira no Estado de São Paulo. 2 ed. Campinas: CATI, 2010. 163 p. (Manual técnico, 72)

6. Hallé, F. ; Martin, R. Etudé de la croissance rythmique chez l'hevea (Hevea brasiliensis). Andasonia, Paris, v.2, n.8, p.475-503, 1968.

7. Herman, M.; Hussey, R.S.; Boerma, H.R. Interactions between Meloidogyne incognita and Pratylenchus brachyurus on soybean. Journal of Nematology, Hanover, Pa, v.20. n.1, p.79-84, 1988.

8. Inomoto, M.M.; Oliveira, C.M.G.; Mazzafera, P. ; Gonçalves, W. Effects of Pratylenchus brachyurus and P. coffea on seedlings of Coffea arabica. Journal of Nematology, Hanover, Pa, v.30. n.3, p.362367, 1998.

9. Khan, F.A. Multiplication rates of Pratylenchus brachyurus in some vegetable crops in northern Nigeria. Crop Protection, Guildford, v.11, p.127-130, 1992.

10. Lordello, L.G.E.; Veiga, A.S. Nematóides em seringueira. Revista de Agricultura, Piracicaba, SP, v.58, n.3, p. 203-207, 1983.

11. Martinez, A.A.; Lordello, L.G.E.; Lordello, R.R.A. Nota sobre os nematóides que atacam a seringueira no Estado de São Paulo. Revista 
de Agricultura, Piracicaba, SP, v. 47, n.3-4, p.159-160, 1972.

12. Medrado, M.J.S.; Bernardes, M.S.; Costa, J.D.; Martins, A.N. Formação de mudas e plantio de seringueira. Piracicaba: ESALQ-Departamento de Agricultura, 1992. 158 p.

13. Paes, V. dos S.; Soares, P.L.M.; Carneiro, F.A.; Santos, J.M. dos; Brito, P.F. de; Miranda, M.D. Ocorrência de nematoides em viveiros de mudas de seringueira no Estado de São Paulo. In: Congresso brasileiro de fitossanidade, 2., 2013, Jaboticabal. Anais. Jaboticabal: UNESP, 2013. p.446-449.

14. Rao, B.S. Pest of hevea plantations in Malaya. Kuala Lumpur: Rubber Research Institute of Malaya, 1965. 98 p.

15. Riedel, R.M.; Foster, J.G.; Mai, W.F. A simplified medium for monoxinic culture of Pratylenchus penetrans and Ditylenchus dipsaci. Journal of Nematology, Hanover, Pa, v.5, n.1, p.71-72, 1973.
16. Rocha Neto, O.G.; Cano, M.A.O.; Tiebaut, J.T.L. Eficiência do uso da água em plântulas de seringueira submetidas a déficit hídrico. Pesquisa Agropecuária Brasileira, Brasília, DF, v.18, n.4, p.363-369, 1983.

17. São Paulo. (Estado). Resolução SAA n ${ }^{\circ} 154$. Estabelece exigências para mudas, borbulhas e sementes de seringueira (Heva spp.) no Estado de São Paulo. Diário Oficial, São Paulo, SP, 23 de Novembro de 2013, v. 123 , n. 221, seção 1, p. 27-28.

18. Southey, J.F. (Ed.) Laboratory methods for work with plant and soil nematodes. $6^{\text {th }}$ ed. London: Ministry of Agriculture, Fisheries and Food, 1986. 202 p. (Reference book, 402)

19. Suatmadji, R.W.; Rao, B.S. Os nuevos nematodos del caucho. Boletim Fitossanitário de la FAO, Roma, v.25, n.1, p.43-44, 1977.

20. Zonta, E.P.; Machado, A.A. Sanest: Análise estatística para microcomputadores. Piracicaba: ESALQ/USP, 1992. 155 p. 